\title{
Application of Reservoir Characterization and Advanced Technology to Improve Recovery and Economics in a Lower Quality Shallow Shelf San Andres Reservoir
}

\author{
Quarterly Report \\ October 1 - December 31, 1997
}

\author{
By: \\ Archie R. Taylor; T. Scott Hickman; James J. Justice
}

Work Performed Under Contract No.: DE-FC22-94BC14990

For

U.S. Department of Energy

Office of Fossil Energy

Federal Energy Technology Center

P.O. Box 880

Morgantown, West Virginia 26507-0880

By
OXY USA Inc.
P. O. Box 50250

Midland, Texas 79710-0250 


\section{Disclaimer}

This report was prepared as an account of work sponsored by an agency of the United States Government. Neither the United States Government nor any agency thereof, nor any of their employees, makes any warranty, express or implied, or assumes any legal liability or responsibility for the accuracy, completeness, or usefulness of any information, apparatus, product, or process disclosed, or represents that its use would not infringe privately owned rights. Reference herein to any specific commercial product, process, or service by trade

name, trademark, manufacturer, or otherwise does not necessarily constitute or imply its endorsement, recommendation, or favoring by the United States Government or any agency thereof. The views and opinions of authors expressed herein do not necessarily state or reflect those of the United States Government or any agency thereof. 
Application of Reservoir Characterization and Advanced Technology to Improve Recovery and Economics in a Lower Quality Shallow Shelf San Andres Reservoir

Quarterly Technical Report

Reporting Period: 10/01/1997 To 12/31/1997

Authors: Archie R. Taylor, T. Scott Hickman, James J. Justice

Report Issue Date: 1/31/1998

DE-FC22-94BC14990--15

OXY USA Inc.

P.O. Box 50250

Midland Tx. 79710-0250

T.Scott Hickman and Associates

550 West Texas Street

Suite 950

Midland, Tx. 79701

Advanced Reservoir Technologies

P.O. Box 985

Addison, Tx. 75001-0985 


\section{DISCLAIMER}

This report was prepared as an account of work sponsored by an agency of the United States Government. Neither the United States Government nor any agency thereof, nor any of their employees, makes any warranty, express or implied, or assumes any legal liability or responsibility for the accuracy, completeness, or usefulness of any information, apparatus or product, or represents that its use would not infringe privately owned rights. Reference to any specific commercial product, process or service by trade name, trademark, manufacturer, or otherwise does not necessarily constitute or imply its endorsement, recommendation, or favoring by the United States Government or any agency thereof. The views and opinions of authors expressed herein do not necessarily state or reflect those of the United States Government of any agency thereof.

\section{OBJECTIVES}

The Class 2 Project at West Welch was designed to demonstrate the use of advanced technologies to enhance the economics of improved oil recovery (IOR) projects in lower quality Shallow Shelf Carbonate (SSC) reservoirs, resulting in recovery of additional oil that would otherwise be left in the reservoir at project abandonment. Accurate reservoir description is critical to the effective evaluation and efficient design of IOR projects in the heterogeneous SSC reservoirs. Therefore, the majority of Budget Period 1 was devoted to reservoir characterization. Technologies being demonstrated include:

1.Advanced petrophysics

2.Three-dimensional (3-D) seismic

3.Cross-well bore tomography

4.Advanced reservoir simulation

5.Carbon dioxide $\left(\mathrm{CO}_{2}\right)$ stimulation treatments

6.Hydraulic fracturing design and monitoring

7.Mobility control agents

\section{SUMMARY OF TECHNICAL PROGRESS}

West Welch Unit is one of four large waterflood units in the Welch Field in the northwestern portion of Dawson County, Texas. The Welch Field was discovered in the early 1940's and produces oil under a solution gas drive mechanism from the San Andres formation at approximately $4800 \mathrm{ft}$. The field has been under waterflood for 30 years and a significant portion has been infill-drilled on 20-ac density. A 1982-86 pilot $\mathrm{CO}_{2}$ injection project in the offsetting South Welch Unit yielded positive results. Recent installation of a $\mathrm{CO}_{2}$ pipeline near the field allowed the phased development of a miscible $\mathrm{CO}_{2}$ injection project at the South Welch Unit.

The reservoir quality at the West Welch Unit is poorer than other San Andres reservoirs due to its relative position to sea level during deposition. Because of the proximity of a $\mathrm{CO}_{2}$ source and the $\mathrm{CO}_{2}$ operating experience that would be available from 
the South Welch Unit, West Welch Unit is an ideal location for demonstrating methods for enhancing economics of IOR projects in lower quality SSC reservoirs. This Class 2 project concentrates on the efficient design of a miscible $\mathrm{CO}_{2}$ project based on detailed reservoir characterization from advanced petrophysics, 3-D seismic interpretations and cross wellbore tomography interpretations.

During the quarter, development of the project's south expansion area was undertaken, work was continued on interpreting the crosswell seismic data and $\mathrm{CO}_{2}$ injection into 11 wells was initiated.

\section{3-D SEISMIC INTEGRATION}

Five new wells were drilled in the south expansion area with good results. Porosity values were close to that predicted by the seismic. The wells were about 15 feet lower than expected, indicating the structure falls off quicker than anticipated but the difference is within the error bands of the surface seismic. The additional wells may be drilled for water injection if subsequent production and completion data show the pressure support is needed.

\section{CROSS WELL SEISMIC}

In the fourth quarter, ART continued work on analyzing and developing processing procedures for interwell reflection data. Much of the effort focused on overcoming the increased complexity of data recorded with fixed source and moving receivers. One-half of each interwell reflection data set had to be recorded with this configuration during the data acquisition in Phase I. Processing improvements were applied to seven of the interwell lines acquired during Phase I work, extending the processed data over the entire span from source well to receiver well. Investigation continued into the complexities of reflective data from points lying very close to either source or receiver well. Such data suffers interference from the (very strong) direct transmission wave, which arrives almost simultaneously with the reflection data at receivers near the reflecting interface. A reliable solution is required to completely image interwell reflection data originating from reflection points in close proximity to either the source or receiver well. Some progress has been made on this problem.

The dominant frequency recorded in these data sets was on the order of 600 to 700 $\mathrm{Hz}$, over interwell distances characteristic of many reservoirs. This points out the potential of this type of imaging for achieving detailed reservoir characterization studies. With good data, reliable ties can be established between the imaged reflection data in depth and the depth synthetics, derived from sonic logs available from wells at the study site. Spatial wavelengths of approximately $30 \mathrm{ft}$. provide the best ties, and correspond to the dominant frequency ranges $(600-700 \mathrm{~Hz})$ obtained in the recorded data (this is a high seismic velocity regime). A considerable effort was devoted to generating synthetics and tying them to the reflection data. The experienced gained so for will greatly improve the 
acquisition and processing of the monitor surveys to be carried out in Phase II of the project.

\section{NUMERICAL SIMULATION}

During the fourth quarter, $\mathrm{CO}_{2}$ injection operations began in the field. Actual injection rates were very close to the seismic-enhanced model predicted rates during this initial injection period. These rates are based on relative permeability curves with higher residual oil saturation to waterflood than used for the base geologic model. The higher residual oil results in higher oil recovery per pore volume than for higher quality reservoirs and could offset the delayed response time from marginal reservoirs. If actual oil production matches that forecasted by the seismic-enhanced model, it would demonstrate that the lower quality reservoirs can be successfully $\mathrm{CO}_{2}$ flooded.

An additional investigation of the effect the fracture length has on oil recovery by $\mathrm{CO}_{2}$ was started. The results from the 3D-fracture model have shown that 400 -ft fracture lengths will grow the fracture out-of-zone. Procedures to keep the fracture from growing are available, but their practicality will depend on a comparison of the effect on performance between 400 -ft fractures and shorter fractures.

\section{AREA PREPARATION AND CONSTRUCTION}

$\mathrm{CO}_{2}$ injection began October 2, 1997 into 11 of the injection wells in Area 2 of the project. The other wells scheduled for $\mathrm{CO}_{2}$ service were kept on water injection due to unexpected low reservoir pressure. The north row of injectors have not been converted to injection, pending the results of the drilling and possible extension of injection to the new wells in the south. Average $\mathrm{CO}_{2}$ injection rates by month were:

\section{October $2187 \mathrm{mscfd}$ \\ November 3780 mscfd \\ December 4596 mscfd}

Nineteen producing wells were worked over during the quarter. Workovers included; lowering pumps, installing tubing and gas anchors, cleanouts and reperforating.

Two-inch PVC flowlines are being replaced with 3-inch fiberglass lines to reduce future gas gathering problems. Ninety percent of the lines have been replaced with the remainder to be finished in January 1998.

\section{TECHNOLOGY TRANSFER}

George Watts presented the seismic guided mapping techniques ${ }^{1}$ to the Society of Exploration Geophysicists at a workshop in Dallas during their annual meeting and international exposition November 2-7, 1997. Archie Taylor presented the integrated well 
logging methods ${ }^{2}$ at the DOE-sponsored logging symposium held in Midland, November 13, 1997.

Two papers covering the simulation work were submitted to the SPE Permian Basin Oil and Gas Recovery Conference for presentation in April 1998.

\section{REFERENCES}

1. Watts, G.P., Hinterlong, G.D. etal, "Seismic Estimate of Porosity in a Permian San Andres Carbonate Reservoir, Welch Field, Dawson County, Texas," March 1996 Proceedings: Oklahoma Geological Society Workshop on Platform Carbonates of the Southern Mid-continent.

2. G. D. Hinterlong and A. R. Taylor, "Combing Flow Theory and Multiple Log Readings to Improve Permeability Calculations", November 13, 1997 Proceedings: Advanced Applications of Wireline Logging for Improved Oil Recovery Workshop. 